\title{
Disaster and after: Hamlet as metaphor in Fin-de-Siècle Spain ${ }^{1}$
}

\author{
Keith Gregor \\ Universidad de Murcia
}

\begin{abstract}
The paper explores the philosophical debates raging in Spain following naval defeat by the US in 1898 and the subsequent loss of the country's last remaining colonies in the Caribbean and the Pacific. Facing what the national press presented as a debilitating pessimism and paralysis - a result of humiliation by a vastly superior and technologically advanced power - a group of intellectuals known as the "Generation of ' 98 " launched a strident campaign aimed at rebooting the nation's social, economic and cultural identity, in which the Spanish nation was imaginatively recast as a kind of Hamlet awaiting the arrival of Fortinbras. The various implications of the Spain-as-Hamlet trope are considered, especially in the light of the play's minimal impact on cultural production at the turn of the century. Not the least of the paradoxes surrounding the trope is the conflicting uses to which it was put: now a metaphor for the decadence of Spanish social and political life, now a source of inspiration for the call for regeneration; now a mode of emplotting the break-up of the nation-state, now a way of framing the question of national unity.

KEY WORDS: Shakespeare, Hamlet, Spain, Generation of '98, national press, metaphor, emplotment.
\end{abstract}

The issue of ideology points to the fact that there is no value-neutral mode of emplotment, explanation, or even description of any field of events, whether imaginary or real, and suggests that the very use of

\footnotetext{
${ }^{1}$ Research for this article was funded by the Dirección General de Investigación of the Spanish Ministry of Science and Innovation under Project FFI2008-01969, "La presencia de Shakespeare en España en el marco de su recepción europea."
}

$$
\text { (G) ederi } 22 \text { (2012: 155-169) }
$$


language itself implies or entails a specific posture before the world which is ethical, ideological, or more generally political: not only all interpretation, but also all language is politically contaminated. (White 1990:129)

"Let's make it very clear: the sea is not to blame." So, in incongruously waggish vein, began a self-styled "report" into the blowing up of the battleship USS Maine in Havana harbour on the evening of 15 February 1898 with the loss of over 260 American lives. After rehearsing some of the theories that were raised at the subsequent inquiry into the causes of the explosion, the report, published in the satirical Spanish review Gedeón on 12 May 1898, accepts "spontaneous combustion" as the most likely. But there is also a suggestion, to which the alleged recovery by Spanish divers of a woman's hat from amongst the various items of clothing found on the wreck seemed to give credence, that "some other liquid element" may have been at fault. Though not openly accusing US tars of engaging in a drunken orgy which prevented them from tending to the ship's dangerously overheating boilers, the author sows a seed of doubt: "That ist the question [sic], as Hamlet says in his famous monologue or philosophical binge." ${ }^{2}$ Though the inquest into the destruction of the Maine seemed to clear Spain from any implication in the tragedy, it was, I suppose, inevitable that the subsequent insinuations by the American gutter press, the US blockade of what was, technically, still a Spanish colony and the declaration of war between the two countries in April, would encourage such aspersions. Spain's defeat at the battle of Cavite (Philippines) on 1 May was still agonizingly fresh in readers' minds, so that this rather unsubtle form of anti-Yankeeism had a topicality which journals like Gedeón were quick to exploit.

More striking is the invocation of Hamlet as a way of lending "philosophical" weight to the doubt-sowing. The mangling of the English may not have been intentional - there is, I think, no attempt to suggest that Hamlet was soliloquizing while under the influence, that drink was somehow slurring his speech, just as the inebriated sailors were distracted from their duties aboard the Maine. Rather, at

2 "Ante todo, el mar es inocente" [...] "combustión espontánea" [...] "algún otro líquido" [...] "That ist the questión, como dice Hamlet en su famoso monólogo ó curda filosófoca." (All translations are my own). 
this early propagandistic stage of the conflict, the mere fact of citing such a prestigious Anglo-Saxon author as Shakespeare, and of doing so from such a culturally authoritative text as Hamlet, was not simply a means of answering the stereotypical anti-Spanish jibes in the American press, but a (possibly unconscious) attempt to discursively outmanoeuvre the aggressor nation by quoting one of its own most charismatic language-founders back at it. Following the next and definitive naval debacle at Santiago de Cuba, where on 3 July a hopelessly antiquated Spanish fleet was (literally) blown out of the water by formidable, iron-clad US vessels, the colonial snipe was, by September, being turned inwards to address the sheer inadequacy of Spain's machinery of war: "Hamlet's famous phrase 'all is rotten in Denmark' [sic] can to no country be more graphically and meaningfully applied than to [Spain]" (30/o9/1898). ${ }^{3}$ The indignation voiced in this three-part critique of "our naval campaign" in the Catholic daily El siglo futuro - an indignation reflected in the generalization of Shakespeare's "something" to "all" aspects of Spain's cock-eyed war preparations - was echoed in a number of reports on "the Disaster" which sought to expose the chasm between American military efficiency and the typically complacent approach to naval architecture, strategy and officerappointment which had dogged Spain since the sixteenth century.

Inevitably, what began life as a reflexion on Spain's deficient military capability among conservative sectors such as El siglo futuro soon grew into a full-blooded attack on the outmoded mechanisms of state. "Oldness," observed the writer "Azorín" (José Martínez Ruiz) in a retrospective account of 1913, "is that which has never had the consistency of the real, or that which, having once possessed it, has ceased to do so and become threadbare and worm-eaten." In the specific context of end-of-the century Spain, "oldness" was felt to be at the very heart of the country's ills:

the vicious practices of its politics, the corruption of the administration, the incompetence, the rackets, the nepotism, the electioneering, the verbal incontinence, the procrastination, the parliamentary fiddling, the rhetorical sallies, the "political conveniences" which lead well-meaning spirits astray; the rigging of elections, the placing of people of influence on the boards and

3 “La célebre frase del Hamlet, 'todo está podrido en Dinamarca', en ningún país del mundo tiene una aplicación más gráfica y significativa que en el nuestro." 
management of major companies, the useless cogs of bureaucracy [...] (Azorín 1969:36)

Little wonder that, after its traditional summer recess, Parliament should re-open in October 1899 to what the liberal newssheet Heraldo de Madrid described as a mood of "fateful lethargy" - a reluctance, or simply an inability, to carry through the wide-ranging reforms the Disaster had seemed to make so pressing. "There was a stench of something rotten in Denmark," wrote the Heraldo's parliamentary reporter on 31 October, reviving a by now much-used Hamlet trope; ${ }^{5}$ "there was a stench of death in the Spanish parliament yesterday." ${ }^{6}$ Without quite reaching the apocalyptic proportions suggested by this report, the fateful lethargy, compounded by the endemic political and administrative ills which the system of pre-arranged power-sharing, or "turno politico," between the two main parties (liberal and conservative) did little to alleviate, was, as a result of the defeat, recognized as having permeated whole swathes of Spanish social life. ${ }^{7}$ Whereas the unexpected defeat of General Cronje in the

4 "Lo Viejo es lo que no ha tenido nunca consistencia de realidad, o lo que habiéndola tenido un momento, ha dejado de tenerla para ajarse y carcomerse" [...] "las prácticas viciosas de nuestra política, las corruptelas administrativas, la incompetencia, el chanchullo, el nepotismo, el caciquismo, la verborrea, el "mañana", la trapacería parlamentaria, el atraco en forma de discurso grandilocuente, las 'conveniencias' políticas que hacen desviarse de su marcha a los espíritus bien inclinados, las elecciones falseadas, los consejos y cargos de grandes Compañías puestos en manos de personajes influyentes, los engranajes burocráticos inútiles [...]"

${ }^{5}$ Not just in relation to Spain or to Spanish politics; there is an almost audible sense of relief in El siglo futuro (18/07/1899) for example, when it is able to apply the same image to a France still reeling from the Dreyfus case: "That phrase of Shakespeare's, which has been repeated so often since he wrote it - Something is rotten in the state of Denmark - is as applicable to this case as it is to many other cases of social pathology" ["Aquella frase de Shakspeare (sic), tan repetida desde que él la escribió... Something is rotten in the state of Denmark... tiene aplicación á este como á otros muchos casos de patología social"].

6 "Letargo funesto" [...] "A podrido olía en Dinamarca [...] A muerto olía ayer en el recinto de las Cámaras españolas"

${ }^{7}$ In the capital Madrid, for instance, the years 1888-1898 alone had seen the burial in the city's recently inaugurated Cementerio del Este of no fewer than 200,000 bodies, evidence of what the Heraldo de Madrid (16/10/1898), again invoking Hamlet, would denounce as a "social crime" to which the authorities seemed unsettlingly indifferent: "'To die... To sleep,' murmurs Hamlet, and the rogue from Madrid who, in ten years' time will be amongst the 200,000 residents of the planned Necropolis, settles the matter in his cocky, street-wise way, by saying: 'To die... To sleep... It's the same thing'" ["Morir... Dormir - murmura Hamlet - Y el golfo madrileño, que dentro de 
Boer War was seen in 1901 as boosting English morale, changing "Hamlet's black despair for the joyous ebullience of The Merry Wives of Windsor" (El Imparcial, 09/03/1901), ${ }^{8}$ Spanish society remained under a heavy cloud. The rot which had set in, and which was nowhere more visible than in the very sectors which denounced it, ${ }^{9}$ seemed so severe that even basic services had lost their age-old reliability. When in September 1901 a Madrid coachman was found and tried for sleeping on the job, there could, according to the liberal El Globo (04/o9/1901), be only one conclusion: "The coachman [was] right: we are all asleep. Dreams, dreams, dreams, as Hamlet would say in one of his philosophical outpourings." ${ }^{\prime 10}$

The adoption of Hamlet as a mode of explanation, and of its central character as mouthpiece of the gloomy and debilitating defeatism which followed the war with the United States, is all the more striking given what, by general European standards, was the play's limited presence in Spanish culture. When Sarah Bernhardt brought her own production of the play to Madrid in November 1899, there was an almost unanimously rapturous response to the performance of a much-neglected work, together with widespread applause for Bernhardt's finely nuanced and "idealist" interpretation of the role of Hamlet. ${ }^{11}$ But the prevailing vision of the play and of its

diez años será contado entre los doscientos mil habitantes de la proyectada Necrópolis, resuelve el problema diciendo con su desenvoltura de gorrión callejero: Morir... Dormir... son la misma cosa"].

8 "a la negra desesperación de Hamlet ha sucedido el rebullicio jocoso de las Alegres comadres"

9 See, for instance, the trashing of the "pornographic" liberal press by El siglo futuro (27/03/1901) which, recalling and correcting its own use of the favoured Hamlet trope, would assert: "[W]e used to be modest and, like Hamlet, say there was something rotten in the state of Denmark. With their constant bickering, the liberal parties and press have clearly displayed that in Denmark everything is rotten now" ["nosotros éramos modestos, y solíamos decir, con Hamlet, que había algo podrido en Dinamarca. Los partidos y los periódicos liberales en sus continuas pelazas son los que nos han demostrado plenamente que en Dinamarca está ya todo podrido"].

10 "Tiene razón el cochero: estamos dormidos. Sueños, sueños, sueños, que diría Hamlet en un retillo de filosofía."

${ }^{11}$ For a typical instance, see the review in El Globo (6/11/1899) which is careful to distance Bernhardt's Hamlet from any associations with the present moment: "The lonely spirits, the taciturn ones, those that nourish the chimera of an unfulfilled ideal, those that brood on the impossibility of happiness, those that protest alone and in silence at the barbarous chasm between what we aspire to and what life has to offer; 
protagonist continued to be firmly linked to the tragedy then unfolding in post-war Spain. "These days the Spanish are like one big Hamlet," announced the Catalan poet Joan Maragall in the Diario de Barcelona in April that same year. Citing the prince's recognition of his own incapacity to carry out the revenge ("O cursed spite, | That ever I was born to set it right"), Maragall identifies a similar impotence in his countrymen:

They also have had tremendous iniquities revealed to them and, when faced with the duty of repairing them and of regenerating themselves, they have exclaimed: "That ever we were born!", because the moment of revelation has been accompanied by a sense of their own weakness. That is why, like Hamlet, they dither and hallucinate. They claim the need to discover the truth of their ignominy before radically undertaking the redress but, deep down, what they really want is to defer it, because they do not feel strong enough to carry it through. (Pujante \& Campillo 2007:362-363) $)^{12}$

Conceived as prototype of the dubitative Spanish intellectual, Hamlet is both appalled by the revelation of the painful truth - in this case, Spain's failure to adapt to the times and manifest inferiority to a "New World" power like the States, at whose hands it has suffered a calamitous defeat - and yet too debilitated, too insecure to react positively to the crisis of values the debacle has brought to the surface. Hamletismo ("Hamletism") became a byword among disaffected intellectuals and an increasingly belligerent press for the empty rhetorical posturing and histrionics which

these are the ones that will understand me, for at some stage it is they who have felt their souls to be in touch with the soul of Hamlet." ["Los espíritus solitarios, los taciturnos, los que llevan en el pensamiento la quimera de un ideal que no llega á prender en la realidad, los que se recogen á pensar en la imposibilidad de la dicha, los que protestan á solas y en silencio de la bárbara desproporción que separa nuestras aspiraciones de lo que nos ofrece la vida, esos me comprenderán, porque habrán sentido alguna vez su alma en contacto con el alma de Hamlet."]

12 "Hoy el pueblo español es un gran Hamlet. También le han sido reveladas tremendas iniquidades y, al imponérsele el deber de repararlas y de regenerarse, ha podido exclamar: '¡Ojalá no hubiera nacido!', porque el sentimiento de su debilidad se le ha aparecido simultáneo con aquella revelación. Por esto, como Hamlet, desvaría y duda. Finge querer averiguar toda la verdad de su ignominia ante de emprender radicalmente la reparación, pero, en el fondo, lo que quiere es dilatarla, porque no se siente con fuerzas para acometerla." 
accompanied defeat. ${ }^{13}$ When, under the terms of the 1898 Treaty of Paris, Spain relinquished all claims to its former colonies in both Cuba and the Philippines and also Puerto Rico and Guam, Hamlet was once again invoked to register Spanish indignation at this "unkindest cut of all" (El Día, 27/o1/1899) but also more tortuously, just five days after the signing of a treaty which also put an end to Spanish sovereignty in the West Indies, in an article called "Asking for the moon" ["Pedir la luna"], at the sheer untenability of the demand of the Liberal party, led by Práxedes Mateo Sagasta, for the immediate dissolution of parliament and the holding of fresh elections: "There are more things in heaven and earth than are written down in books [sic]" (La Época, 15/12/ 1898). ${ }^{14}$

The articulation of radical pessimism was, to be fair, not the only use to which Hamlet was put in the period immediately after the rout and subsequent loss of the colonies. In a hard-hitting article in the progressive Revista contemporánea, dated July 1898, the play is already cited as a rationale for the adoption of positive solutions to the crisis:

Either Spain is regenerated by means of peaceful evolution (as has been the case after defeat in countries like Russia, Austria and France in the last fifty years), through the unwavering cauterization of her wounds and the satiation of the desires for justice, rectitude and progress currently sweeping the nation, or she will continue to be governed by her impenitent politicians with the same violence and falsehoods they have used in recent

\footnotetext{
13 See Granjel (1973:78) and Gregor (2010:73-74). Compare the use of the term "Hamletism" from the 184 os on in Europe to denote an attitude to life which is "wellintentioned but ineffectual, full of talk but unable to achieve anything, addicted to melancholy and sickened by the world around [us]" (Foakes 1993:20; see also Han 2001:21). The most expansive use of the Hamlet-trope was without doubt in Germany, where poet Ferdinand Freiligrath's identification "Deutschland ist Hamlet" inaugurated an aggressive series of calls to national self-assertion, not dissimilar to those made half a century later in Spain (see, amongst many other studies, Pfister 1986).

14 "Hay en la tierra y en los cielos muchas cosas que no están escritas en los libros." (See also the humorous account of the future negotiations in Gedeón [25/08/1898] where, in an unsuccessful pun on Hamlet's famous soliloquy, the mercenary intentions of the Spanish delegation [Spain would eventually accept the US offer of 20 million dollars for the islands] are revealed as "To by or not to by; that is the question".)
} 
years. Recalling the dilemma of Hamlet, which seems most timely at the present moment: To be or not to be; that is the question. ${ }^{15}$

"To be" was, in these terms, to cease to endorse the paralyzing system of two-party alternation, as well as the corruption and social and economic stagnation associated with it, and to face head-on the age-old problems which had reduced Spain from colonial potentate to second-rate geopolitical backwater, with neither the capacity nor the desire for change. It was largely to prick consciences and to goad into action both the ruling elite and intellectuals capable of engineering a solution that the leading figures of the so-called "Generation of "98", Ramiro de Maeztu, Azorín and the novelist Pío Baroja, ${ }^{16}$ set out their "Manifesto" of 1901. "Desirous as we are," they stated, "to cooperate, with our modest strength, in the generation of a new social state in Spain," the signatories claimed to be speaking in the name of a "nascent ideal" which they vowed to "translate into concrete facts." Indebted in many ways to the imported philosophy of intellectual progress known as krausismo and the project of a fully lay education embodied in the Institución Libre de Enseñanza (Free Institute of Education), while anxious to distance themselves from the "utopian" discourses of socialism and anarchism which were proliferating at the turn of the century, "the Three," as they were known, placed their faith in science and in a wider tradition of European thought which they traced from the French "Encyclopedists" to Schopenhauer and Nietzsche, all of whom had sought to demonstrate the "relativity of absolute ideas." As to the tangible results (the "concrete facts") of the regeneration they proposed, they aspired to nothing less than

To lay bare the miseries of people in the country, the difficulties and sadness of the thousands of hungry, the horrors of prostitution and alcoholism; to show the necessity of compulsory education, the setting up of agricultural credit banks, the

\footnotetext{
15 “Ó España se regenera por la evolución pacífica - como ha sucedido durante el último siglo á Rusia, Austria y Francia, después de su vencimiento, - aplicando sin contemplaciones el cauterio á sus llagas y satisfaciendo los anhelos de justicia, rectitud y progreso extendidos por todos los ámbitos de la Península, ó continúa gobernada por sus impenitentes políticos con las mismas violencias y mentiras de los últimos años. Recordamos el dilema de Hamlet, muy oportuno en estos momentos: To be or not to be, that is the question."

${ }^{16}$ Significantly, all three of the "98ers" were writers; none of them was a professional politician or had been actively involved in the conflict in the Philippines or in Cuba.
} 
implementation of divorce, as a consequence of the law of civil matrimony. (Cited in Rull 1984:34-35)

Inevitably, such an ambitious project, which was redolent of the short-lived Spanish Constitution of 1812, was greeted with Hamletian scepticism by the popular press or simply went unheeded by the institutions capable of implementing these wide-ranging reforms. "Words, words, words," scoffed the enigmatic columnist "Miss-Teriosa" in El Día (19/11/1898) apropos of what s/he referred to the "apostolic mission" of the regenerationists to scale the rockface of "worn-out organisms and shame-faced complacency." ${ }^{17}$ In a scathing verse "Epistle" published in the satirical Madrid cómico (24/02/1900) Alberto Lozano used Hamlet to pour further scorn on the reformists and their proposal to mobilize women in the regeneration of Spanish institutional and social life:

Now Spain is a madhouse:

Generals, politicians, bullfighters

Friars, pimps, and decadent artists.

Such gentlemen are not to be feared.

You [women] will feel very much at home

And conquer the coveted ground

By fighting all over, so that

Soon you will be assailing the Congress and the Senate

The Courts and the Classrooms, everything,

Everything needs regenerating!

What Hamlet said of his own state, alas

We can now say of our own! $!^{18}$

Here, the all-too-familiar and consequently unstated "Something rotten" is used to denigrate not just the bodies which need reforming but, by implication, the possible agents of that very reform - the women whose empowerment will, it is suggested, merely add to the prevailing lunacy. But it is "Words, words, words" which would win

\footnotetext{
17 "misión apostólica" [...] "organismos caducos y vergonzosas condescencias."

18 "Ya España es un asilo de dementes: | generales, políticos, toreros, | frailes, chulos y artistas decadentes.||No son temibles tales caballeros.|Lograréis encontrar buen acomodo|y conseguir los codiciados fueros||luchando en todas partes, de tal modo |que asaltéis el Congreso y el Senado, | los Tribunales y las Aulas, todo, | | todo tiene que ser regenerado! $\mid$ iLo que del suyo Hamlet, por desgracia|podemos hoy decir de nuestro Estado!"
} 
the day in terms of typifying the inefficacy of the reformist campaigns or, perhaps more accurately, the imperviousness of the state to any radical modification of its bases. So, in an open letter to Juan Navarro Reverter, José María Alonso de Beraza writing in $E l$ Liberal (27/02/1901) could concur with the judgement of the former finance minister that so much talk of Spain's position was detrimental to the economy, while adding that "from the point of view of the regeneration of the country and its exchequer, it is only partly right, since it is not only 'words' but the actual state of chaos which is aggravating the situation." ${ }^{19}$ A year and a half later, in a leader titled simply "Palabras" ("Words"), the Barcelona daily La Dinastía, this time in relation to Prime Minister Sagasta's promise that parliamentarians would forego their vacations to tackle the crisis, was drawn to offer the following analysis:

Words, words, words.

And let it be said that, in the case of the Spanish Hamlet, it is not only we, but the public opinion we have consulted, indeed the country as a whole which has been sufficiently afflicted with unkept promises as to be on its guard yet again. ${ }^{20}$

One of the ironies of the use of Hamlet the character as a kind of negative behavioural model was, as should now be clear, the continued recourse to the text of Hamlet as metaphor for the political, economic and also social circumstances of fin-de-siècle Spain. If Hamletism - the gloomy soul-searching and histrionic rhetoricity which were an impediment to progress - was resented as a basis for both thought and action, there were no such qualms when it came to plumbing Shakespeare's play for authoritative analogues for the process of national reconstruction envisioned by both liberals and conservatives. "Cruel to be kind" was the verdict passed by the "independent" El Día (30/04/1901) on a tram-driver's go-slow which had been crippling the capital Madrid in spring that year: "As

\footnotetext{
19 "Bajo el punto de vista de la regeneración del país y de la Hacienda, es exacto, en cierto modo solamente, porque no son sólo palabras, sino manifestaciones de un desbarajuste que agrava cada vez más la situación."

20 "Palabras, palabras, palabras. Y cuenten que en ese caso el Hamlet español no somos nosotros solos, es la opinión pública por nosotros interpretada, es el país, lo suficientemente escarmentado por anteriores promesas que siempre ha visto incumplidas, para que con razón sobrada se llame á engaño una vez más."
} 
tyranny goes, that which comes from above is to be preferred." ${ }^{21}$ The turn to more authoritarian forms of government is, as Donald Shaw (1982:28) has argued, one of less documented aspects of turn-of-thecentury debates and inflects even the thinking of writers associated with the so-called "Generation of '98." Maragall, whose identification of Spain as "one big Hamlet" I offered above as diagnosis of the contemporary Spanish tragedy, also went on to state:

This evolution and this law [what Maragall describes as the "natural" "transfusion" of energy from less to more "vital" forms of life] are beginning to be accomplished in Spain, at least in those regions which make more of a living from modern life, and are accomplished not, by any means, in the form of armed invasion, or the reduction to slavery, or the annihilation of national identities, but, on the contrary, through the attraction of labour, the solidarity between men of action, the pacific and amorous mixing of blood, assimilation. The renovation has commenced: let us accept it, encourage it, and soon Hamlet will begin to feel the effects of the transfusion of life from Fortinbras. (Pujante \& Campillo 2007:364) 22

Though Maragall himself can be identified with neither the more "authoritarian" stream of Catalanism nor the "strong-armed" sectors of Spanish nationalism, the imaginative turn to Fortinbras - to the "man of action" (literally, "strong in arm"), as opposed to the effete and passive Hamlet - is eerily consistent with the sympathies expressed by some regenerationists for the abolition of the selfperpetuating two-party "turno politico" and its replacement by a more "virile" system of autocracy.

\footnotetext{
21 "Tiranía por tiranía, es preferible la que viene de lo alto." (The article continues: "To put a stop to the other [kind of tyranny], we would have to acknowledge with Hamlet that there are times in life when a man should appear cruel in order to be truly generous'" ["Para acabar con la otra, es preciso reconocer que, como dice Hamlet, 'hay momentos de la vida en las que el hombre debe aparecer cruel para ser verdaderamente generoso'"]).

22 "Esta evolución y esta ley empiezan a cumplirse en España, al menos en aquellas de sus regiones que viven más de la vida moderna, y se cumplen no ciertamente en forma de invasión armada, ni de reducción a esclavitud, ni de aniquilamiento de nacionalidades, sino al contrario, por la atracción del trabajo, por solidaridad de gentes activas, por mezcla pacífica y amorosa de sangres, por asimilación. La renovación está iniciada; aceptémosla, fomentándola, y pronto Hamlet empezará a sentir los efectos de la transfusión de vida de Fortimbrás."
} 
At stake here, ultimately, was the whole question of Spain as a nation. From a Catalanist perspective, "Spain," as centralized nationstate, could easily be written off as a decadent Elsinore awaiting the entry of a triumphal Fortinbras. At the same time, though for many of the regenerationists, Hamlet and "Hamletism" were deeply inimical to the Spanish character which could trace its descent from the idealist or extrovert archetypes embodied by Don Quixote, Don Juan or La Celestina (Maeztu 1968), the state of Spain as national entity was, in the aftermath of the war, regularly defined in terms which invoked the English tragedy. Thus, Spain's decision not to execute Juan Rius Rivera, the rebel leader who had fought the Spanish occupation in both Puerto Rico and Cuba and was imprisoned in Barcelona till the end of the war, was hailed in $\mathrm{La}$ Dinastía (10/07/1898) as an instance of her Catholic Christian magnanimity: in contradistinction to the image of Hamlet "horribly avenging his father," here was a nation which offered that of "Christ nailed to the cross, forgiving His executioners." ${ }^{23}$ And though Sagasta would, in some quarters, be represented as a political equivalent of a Hamletian gravedigger, chatting comically with the prince while secretly disposed "to personally inter both men and ideas, institutions and whole chunks of the homeland" (El Nuevo País, 17/10/1898), ${ }^{24}$ the bulk of the popular press used Hamlet as an image of actual national unity, rather than of fragmentation. Hence, the warm reception of the King and Queen on a visit to the Basque Country in August 1900 was interpreted by the Heraldo de Madrid (17/08/1900) as confirmation of the indivisibility of the kingdom versus the separatist aspirations of certain of its subjects: "Were the structure of unity less solid than it is," stated its leader in a somewhat convoluted image, "the noble, fearsome head of the Spanish lion would in the dainty fingers which, like Hamlet, the skull of York [sic] would seem to have, now lie broken." ${ }^{25}$ Broken it was not, though this did not lessen the dangers of burgeoning nationalism in both the Basque Country and, in a more organized

\footnotetext{
23 "vengando horriblemente a su padre" [...] "Jesucristo clavado en la cruz y perdonando a sus verdugos."

24 "a enterrar por su mano hombres e ideas, instituciones y pedazos de la patria."

25 "A no ser tan firme la obra de la unidad, ya se hubiera roto entre los débiles dedos que parece tener, cual Hamlet, el cráneo de York, la noble y fiera cabeza del león español."
} 
fashion, Catalonia; nor, consequently, did it dampen the calls for national unity and coherence which, in an article entitled "Saluting the flag," "Miss-teriosa" describes as the mainstay of Spanish idealism: "Let us day-dream, if you like, but let us dream nonetheless; let us shake off this 'mortal coil' of which Hamlet speaks and let its pulse be heard" (El Globo 15/01/1901). ${ }^{26}$

It would take another two decades, and the establishment of the royally-sanctioned ultra-conservative military directorate of Miguel Primo de Rivera, who modelled himself on Mussolini, for a Spanish Fortinbras to finally emerge. But the "intellectual" groundwork for a change of regime is already visible in the immediate post-war period where critical discussions of Hamlet, many of them inspired by the Bernhardt production, can be seen serving more or less explicit ideological agendas. One such discussion, serialized in 1900, is Leopoldo Augusto de Cueto (the Marquis of Valmar)'s study "Los hijos vengadores: Orestes, El Cid, Hamlet" [The Avenging Sons: Orestes, El Cid, Hamlet], which presents the turbulent political, social and religious context of early modern England as providing the "natural" conditions for the creation of a character like Hamlet: "A troubled, gloomy spirit, lacking in illusions and enthusiasm, who talks, travails and meditates in abundance, but who is afraid to act and, when the time comes to do so, who vacillates and shies away." Hamlet's incapacity to avenge his father's death on religious grounds - remember Claudius is at prayer at the time - is tartly dismissed as the sanctimonious soul-searching of the impotent: "Such an ingenious hindrance would never have occurred to someone of the mettle of an Orestes or an El Cid" (Pujante \& Campillo 2007:367). ${ }^{27}$ Without going so far as to explicitly link the play's context or the prince's peculiar infirmity to the condition of contemporary Spain, in his overall assessment of Hamlet's character and the flawed dramatic postulates of Shakespeare's tragedy Cueto sends an unequivocally ideological message to his readers:

\footnotetext{
26 "Soñemos despiertos: pero soñemos, al fin, y sacudamos ese 'mortal coil' de que nos habla Hamlet, procurando que se escuchen sus latidos."

27 "Alma desasosegada y tétrica, sin ilusiones, sin entusiasmo; habla, intenta, medita mucho, pero se asusta de la acción y, cuando llega la ocasión de realizarla, vacila y retrocede.... Jamás habría ocurrido tan ingeniosa rémora a hombres del temple de Orestes o del Cid."
} 
All is uncertainty and incompletion in the character of the Danish prince. It is not the impiety of he who ignores and denies the consolation and power of Heaven; nor is it the faith of the believer who heeds and worships the mysteries of God. Rather, he is distrustful of everything, and doubt is his executioner and the source of his weakness. What truth, what force, what integrity can there be in his resolve as an avenging son, if at times he doubts the very nature of the crime he has to avenge, at others the appearance of the king, his father, who instilled such vivid horror in him at the beginning and who in his soul unleashed the helllike passion for revenge? [...] Drama feeds off passion and action, and requires nothing of its characters so much as vigour, singlemindedness, clarity, determination of purpose and mind. This is precisely what is found wanting in Hamlet. (Pujante \& Campillo 2007:368) ${ }^{28}$

The exclusion of Hamlet from theatrical repertoires in the years which followed the Disaster indubitably owes more to aestheticcommercial factors than it does to the aesthetic-ideological objections of critics like Cueto. ${ }^{29}$ Rather than as an anti-recipe for stage performance, the play was more regularly used as an antonym for the kind of hard-nosed naturalism which was favoured by many members of the so-called "Generation of '98."30 Beyond the purely

\footnotetext{
28 "Todo es incierto e incompleto en el carácter del príncipe dinamarqués. No es el impío que desconoce y niega los consuelos y las potestades del cielo; no es tampoco el creyente que acata y venera los misterios divinos. Desconfía de todo, y la duda es su verdugo y la fuente de su flaqueza. ¿Qué verdad, qué ímpetu, qué entereza cabe en su resolución de filial vengador, si duda unas veces del crimen mismo que ha de vengar, y otras de la aparición del rey, su padre, que tan vivo terror le infundió al principio y que desencadenó en su ánimo la infernal pasión de la venganza? [...] El drama vive de pasión y de acción, y nada requiere tanto en los personajes como vigor, fijeza, claridad, determinación de impulsos y carácter. Esto es cabalmente lo que se echa de menos en Hamlet."

${ }^{29}$ For an in-depth study of the production of Hamlet and other canonical Shakespeare plays at the turn of the 19th century and first three decades of the 2oth, see Cerdá (2010).

${ }^{30}$ See, for instance, Rafael Balsa de la Vega who, citing the work of French critic Arsène Alexandre on the demise of symbolism, proposes the following antidote to "symbolic mists" ["brumas simbólicas"] enshrouding Hamlet: "What's needed is an art which is a reflection of the truth, which is sincere, which meets the demands of modern intellectual culture, which addresses the faculty of thought, which doesn't get lost in the clouds [...]" ["Necesitamos un arte que sea reflejo de la verdad, que sea sincera, que responda a las exigencias de la cultura intelectual moderna, que hable al pensamiento, que no vaya por las nubes [...]."] (El Liberal, 18/10/1898).
} 
(8) ederi 22 (2012)

cultural sphere, however, the repeated recourse to Hamlet, which in the national press and increasingly among sectors pressing for independence in the affluent and cosmopolitan region of Catalonia, the welter of allusions to the play, however faulty or tendentious, is evidence of its perceived homology with wider social, political and economic processes.

\section{References}

Azorín [José Martínez Ruiz] 1969. La generación del 98. Salamanca: Anaya.

Cerdá, Juan Francisco 2010. "Shakespeare and the Renovation of Spanish Theatrical Culture (1898-1936)." Ph. Diss. Universidad de Murcia.

Foakes, R. A. 1993. Hamlet versus Lear. Cultural Politics and Shakespeare's Art. Cambridge: Cambridge University Press.

Granjel, Luis S. 1973. La generación literaria del noventa y ocho. Salamanca: Anaya.

Gregor, Keith 2010. Shakespeare in the Spanish Theatre: 1772 to the Present. London \& New York: Continuum.

Han, Younglim 2001. Romantic Shakespeare: from Page to Stage. Cranbury, NJ: Associated University Presses.

Maeztu, Ramiro de 1968. Don Quijote, Don Juan y la Celestina: ensayos en simpatía. Madrid: Espasa-Calpe.

Pfister, Manfred 1986. "'Germany Is Hamlet': the History of a Political Interpretation." New Comparison 2: 106-126.

Pujante, Ángel Luis and Laura Campillo eds. 2007. Shakespeare en España: Textos 1764-1916. Universidad de Granada and Universidad de Murcia: Editum.

Rull, Enrique 1984. El modernismo y la generación del 98. Madrid: Playor.

Shaw, Donald L. 1982. La generación del 98. Trans. Carmen Hierro. Madrid: Cátedra.

White, Hayden 1990 (1978). Tropics of Discourse: Essays in Cultural Criticism. Baltimore \& London: Johns Hopkins University Press.

How to cite this note:

Gregor, Keith. "Disaster and after: Hamlet as metaphor in Fin-de-Siècle Spain." SEDERI 22 (2012): 155-169.

Author's contact: gregork@um.es

Submission: 26/10/2011

Acceptance: 31/01/2012 